\title{
GEOLOGICAL, GEOMORPHOLOGICAL AND TECTONIC STRUCTURE OF NE ATTICA AND SEISMIC HAZARD IMPLICATIONS FOR THE NORTHERN EDGE OF THE ATHENS PLAIN
}

\author{
Papanikolaou D. ${ }^{1}$, and Papanikolaou I. ${ }^{1,2}$ \\ ${ }^{I}$ National and Kapodistrian University of Athens, Faculty of Geology and Geoenvironment, \\ Laboratory on Natural hazards, Department of Dynamic, Tectonic and Applied Geology \\ Panepistimioupolis Zografou, 157-84 Athens, Greece, dpapan@geol.uoa.gr \\ ${ }^{2}$ University College London, Department of Earth Sciences, Benfield-UCL Hazard Research \\ Centre, Gower Str.WCIE6BT London, UK.E-mail: i.papanikolaou@ucl.ac.uk
}

\begin{abstract}
A synthesis of geology, geomorphology and tectonics has been compiled regarding the NE part of Attica. This synthesis helps us clarify how old and new structures interrelate and interact to provide the present day setting. Geological, geomorphological maps, and cross-sections are provided to help us depict and extract data. The region of NE Attica forms a tilted tectonic block bounded by the Afidnai fault to the south and the Oropos fault to the north that rotates to the $S$-SW. This tilt produces southern trending flow directions draining the footwall within the block. Drainage basins are highly asymmetric due to the presence of active normal faults producing a combination of fault parallel and fault perpendicular flow directions. This block is also divided by a NNE-SSW detachment fault that separates the metamorphic units to the east from the unmetamorphic units to the west. It was active in Late Miocene-Early Pliocene and produced several hundred meters of debris-flow deposits. This detachment influences the geometry, style and intensity of deformation, but also the seismicity pattern. In particular, this detachment coincides with the line separating zone I (lowest category of seismic risk) from zone II of the national seismic building code. Finally, the Athens plain is bounded northwards by the active, but low slip-rate E-W trending, $14 \mathrm{~km}$ long, Afidnai fault.
\end{abstract}

Key words: Detachment, active fault, Afidnai, Oropos, Marathon.

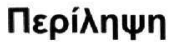

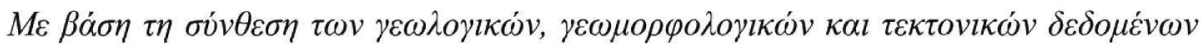

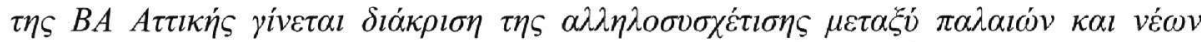

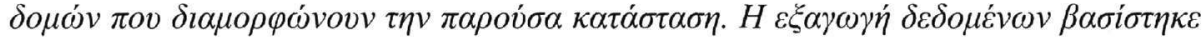

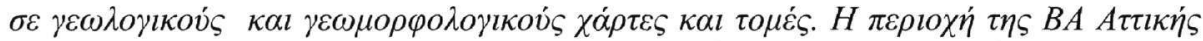

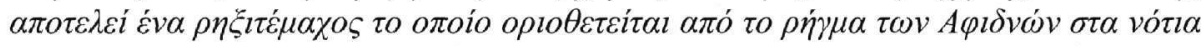

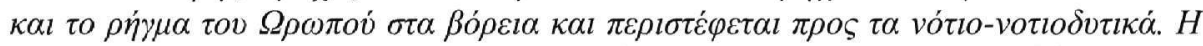

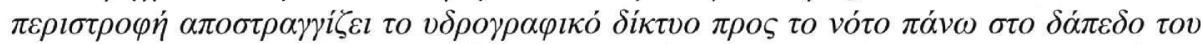

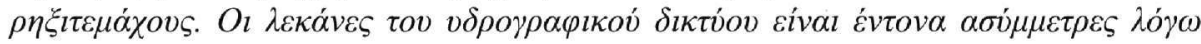




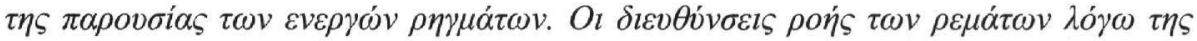

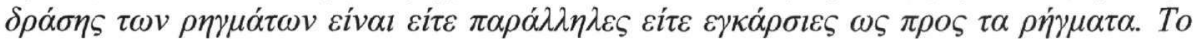

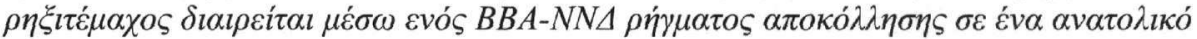

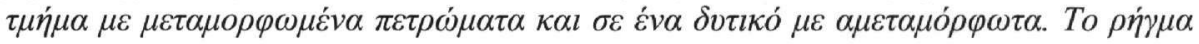

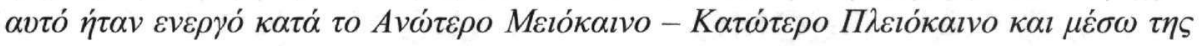

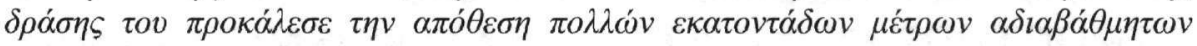

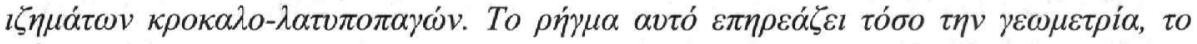

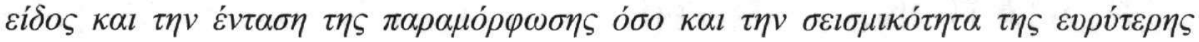

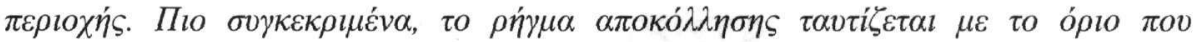

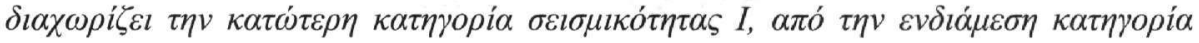

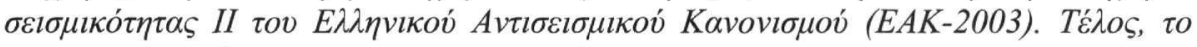

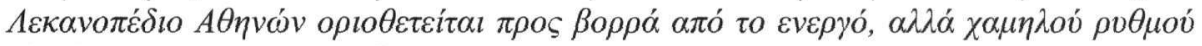

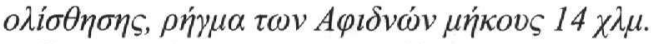

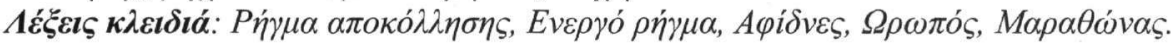

\section{Introduction}

The northeastern part of Attica forms a complex mosaic of old and new structures. These structures shape the present-day geomorphological, neotectonic and seismicity status. In this paper we: a) try to unravel the geological history of the area since the Late Miocene, b) show how these structures interrelate and interact and c) discuss the implications for seismic hazard assessment.

\section{Geological Structure}

\subsection{Geotectonic Units, Alpine rocks and post-Alpine sediments}

Northeastern Attica comprises Alpine basement rocks, both metamorphic and non-metamorphic, and post-Alpine sediments (Fig. 1). The Alpine rocks belong to the metamorphic units of the Northern Cyclades and Almyropotamos that extend from Penteli Mt to the southern Evoikos gulf and to the non-metamorphic unit of Eastern Greece that outcrop in Parnitha Mt (Papanikolaou 1986). The Almyropotamos unit is known from southern Evia, but it crops up also in the area of Marathon. It comprises a thick Mesozoic marble sequence overlain by phyllites representing a metamorphosed Tertiary flysch (Katsikatsos 1969, Dubois and Bignot 1979). The Northern Cyclades unit emerges not only on the northern Cyclades islands, but also in a major part of the southern Evia, where it is known as the Styra unit (Katsikatsos 1979). It consists of thick sequences of mica schists and cipolines grading to siliceous marbles with alternations of greenschists and amphibolites, representing a pelagic volcanosedimentary sequence. More to the south the Northern Cyclades unit is tectonically overlying the relative autochthon unit of Attica (Lozios 1993). The non-metamorphic tectonic unit of Eastern Greece comprises: (i) the SubPelagonian Triassic-Jurassic carbonate platform overlying a volcanosedimentary PermoTriassic complex and underlying an upper Jurassic schist-hornstein melange formation, (ii) the ophiolite nappe of the Vardar/Axios oceanic basin, and (iii) the upper Cretaceous transgressive sequence made of a shallow-water carbonate platform and a Tertiary flysch. Most part of the Parnitha Mountain consists of the lower group (i). The deformation of the Alpine formations of the above units is post-Late Eocene, as dated from the age of the flysch involved in the tectonic structures and extends up to the Early Miocene as the synmetamorphic deformation shows in the metamorphic rocks of the Cyclades (e.g. Schliestedt et al. 1987). 


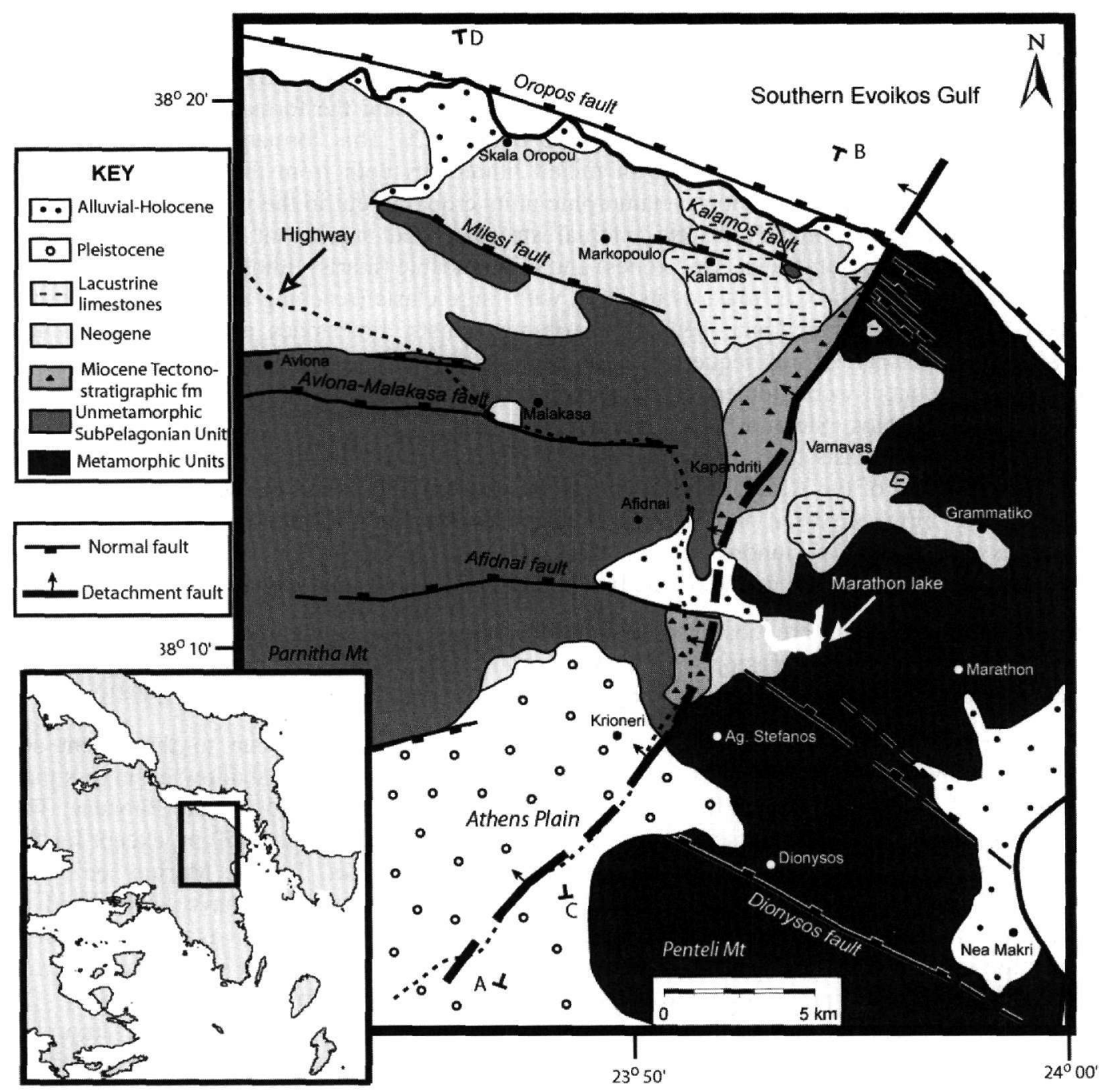

Figure 1 - Geological map of NE Attica

A detachment fault (see below 2.2) separates the metamorphic units from the non-metamorphic units. This detachment passes from the Ochtonia cape in the Aegean coast of Southern Evia (northwards our study area), through Aliveri to Kalamos in northeast Attica and continues to the southwest into the plain of Athens approximately along the Kifissos River (Papanikolaou et al. 1999, Xypolias et al. 2003). Finally, between the metamorphic and the non-metamorphic units and along strike the tectonic contact there is a narrow zone, where some small outcrops of low-grade metamorphic rocks occur under the post-Alpine sediments that cannot be correlated to either of these two units. These rocks might be correlated to the Alepovouni unit or a similar type of unit observed further south (Papanikolaou et al. 2004a), whose lower part comprises a few hundred meters of semi-metamorphic sandstones, schists, and phyllites. The Alepovouni unit is bounded by two detachment faults one separating it from the overlaying unmetamorphic units of Athens and the SubPelagonian and the other detachment from the underlying metamorphic Attica autochthon unit (Papanikolaou et al. 2004a). 
The post-Alpine sediments of the area comprise Late Miocene - Pliocene continental deposits and minor outcrops of Pleistocene and Holocene alluvial (e.g. Mettos 1992). The older sediments comprise a clastic tectonosedimentary formation that outcrops in the area of Kapandriti, and in the area between Aghios Stefanos and Afidnai (Figs 1, 2, 4). They form a NE-SW zone of debris-flow deposits that are several hundred meters thick (Fig. 3), indicating the formation of a major fault zone in a steep relief during Late Miocene (see below 2.2). This formation consists of large boulders and blocks in a clay matrix with mixed lithologies both from the metamorphic units cropping out in the east and the non-metamorphic units cropping out in the west. In Kapandriti, it is characterized by a complex/chaotic internal structure and significant lateral variations of permeable (sands, conglomerates, sandstones) and impermeable (marls) lithologies. Semi-cohesive breccio-conglomerates prevail towards its base, with large clasts (reaching up to a diameter of 2 meters) sourced from the alpine bedrock involving schists, limestones and cherts (Fig. 4a). Towards the upper part of this sequence, clasts become thinner and finer and at places sandstone beds and less frequently conglomerates are also observed. The same formation outcrops also in the area between Aghios Stefanos and Afidnai and has been evolved laterally to breccioconglomerates with clasts that are smaller in size (rarely exceed $30-40 \mathrm{~cm}$ in diameter). In the immediate footwall of the Afindai fault its thickness exceeds $150 \mathrm{~m}$ and the bedding dips $20^{\circ}-40^{\circ}$ towards NNE (Fig. 4b). On top of this breccio-conglomerate formation outcrop lacustrine limestones that are a few hundred meters thick. The top lacustrine limestones are also found unconformably overlying the metamorphic basement in the east around Varnava.

Pleistocene alluvial fans are observed within the Athens plain along the southern slopes of Parnitha Mt and the western slopes of Penteli southwards from the Afidnai and the Aghios Stefanos, uncomformably covering the Neogene sediments (e.g. Papanikolaou et al. 2004b).

No outcrops of marine sediments are traced in Northeastern Attica, due to the recent sea transgression in the southern Evoikos gulf. The southern Evoikos gulf is a shallow basin less than $250 \mathrm{~m}$ deep that separates Attica from the southern Evia and was formed in Late Pliocene. The thickness of the Plio-Quaternary sediments within the gulf does not exceed $150 \mathrm{~m}$, except for the southeastern area, where they are $250 \mathrm{~m}$ thick (Papanikolaou et al. 1988a). Marine sediments occur only along the coast of eastern Attica at Rafina area where they have been dated as uppermost Pliocene - lower Pleistocene (Mitzopoulos 1948, Guernet and Sauvage 1970). Finally, recent alluvial sediments are limited in thickness and are observed only in some small narrow bands along the coastline (Oropos, Kalamos, Marathon) and in the Afidnai basin (Fig. 2). Roubanis (1961) reported that in the Afindai plain close to the railway station, the metamorphic basement was drilled at a depth of $47 \mathrm{~m}$ and that the Neogene sediments were only $15 \mathrm{~m}$ thick, revealing that the Late Pleistocene-Holocene sediments are about $30 \mathrm{~m}$ thick. Recent drillings for water in the Plain also showed that the alluvial- Quaternary thickness does not exceed $80 \mathrm{~m}$.

\subsection{The role of the detachment fault}

The dominant structure is a major NNE-SSW trending detachment, separating the metamorphic units towards the east from the non-metamorphic units towards the west. Moreover, it separates the E-W trending faults in the western part from the NW-SE faults in the eastern part. This detachment caused the downward movement of the non-metarmorphic units and the uplifting of the metamorphic units from the deeper part of the lithosphere where the metamorphism took place in Eocene-Oligocene times. The Miocene tectonosedimentary sequence of debris-flow deposits rests on the hangingwall of the detachment fault and was formed by its activity. This extensional detachment was active throughout Late Miocene times and gradually became inactive during Early Pliocene, when lacustrine deposits have been accumulated all over the area from Varnava and Kapandriti to Kalamos (Fig. 1). The same detachment can be traced further south. In particular, it has subsided the non-metamorphic SubPelagonian unit towards the NNW and uplifted the Alepovouni and the Attica autochthon to the SSE (Papanikolaou et al. 2004a). 


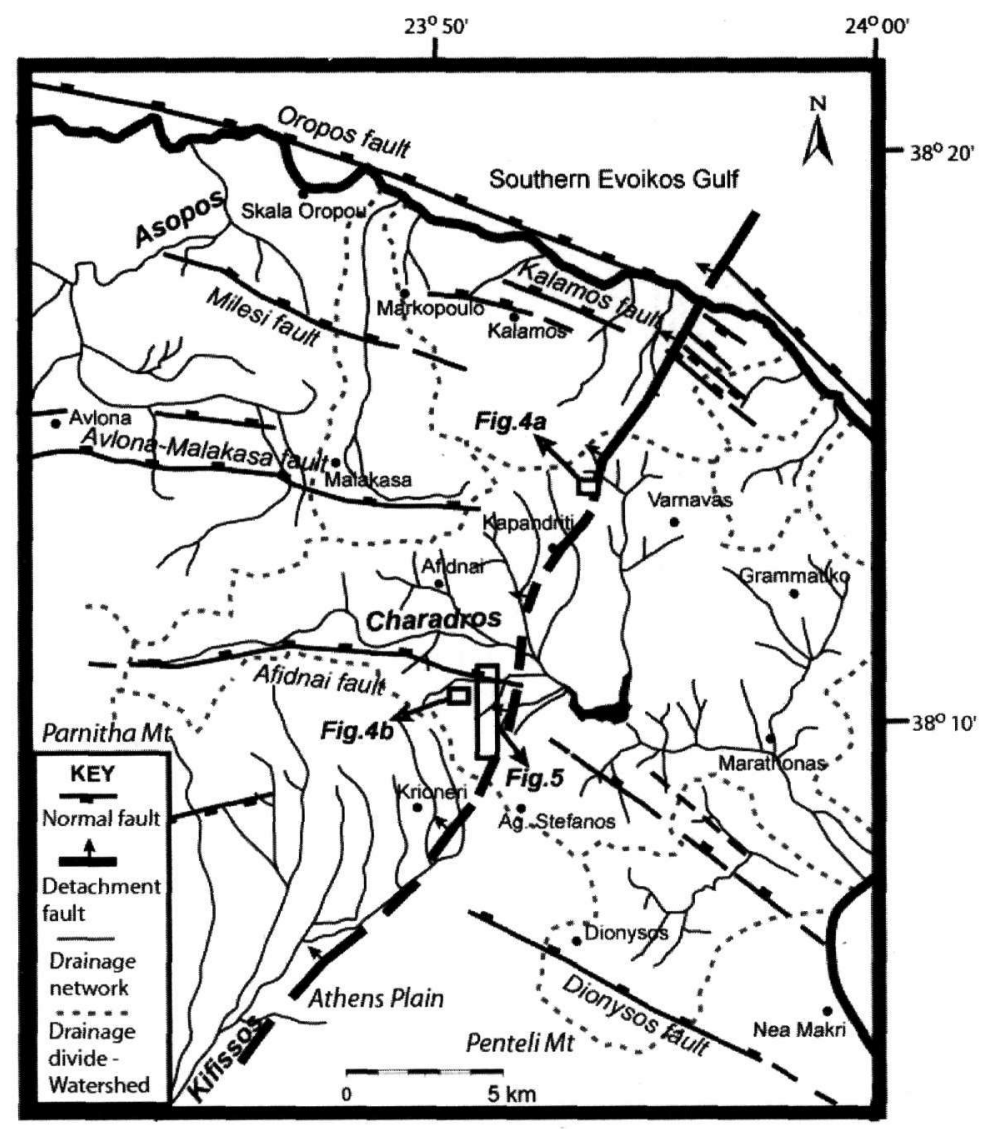

Figure 2 - Drainage network, drainage divide and active faults in NE Attica
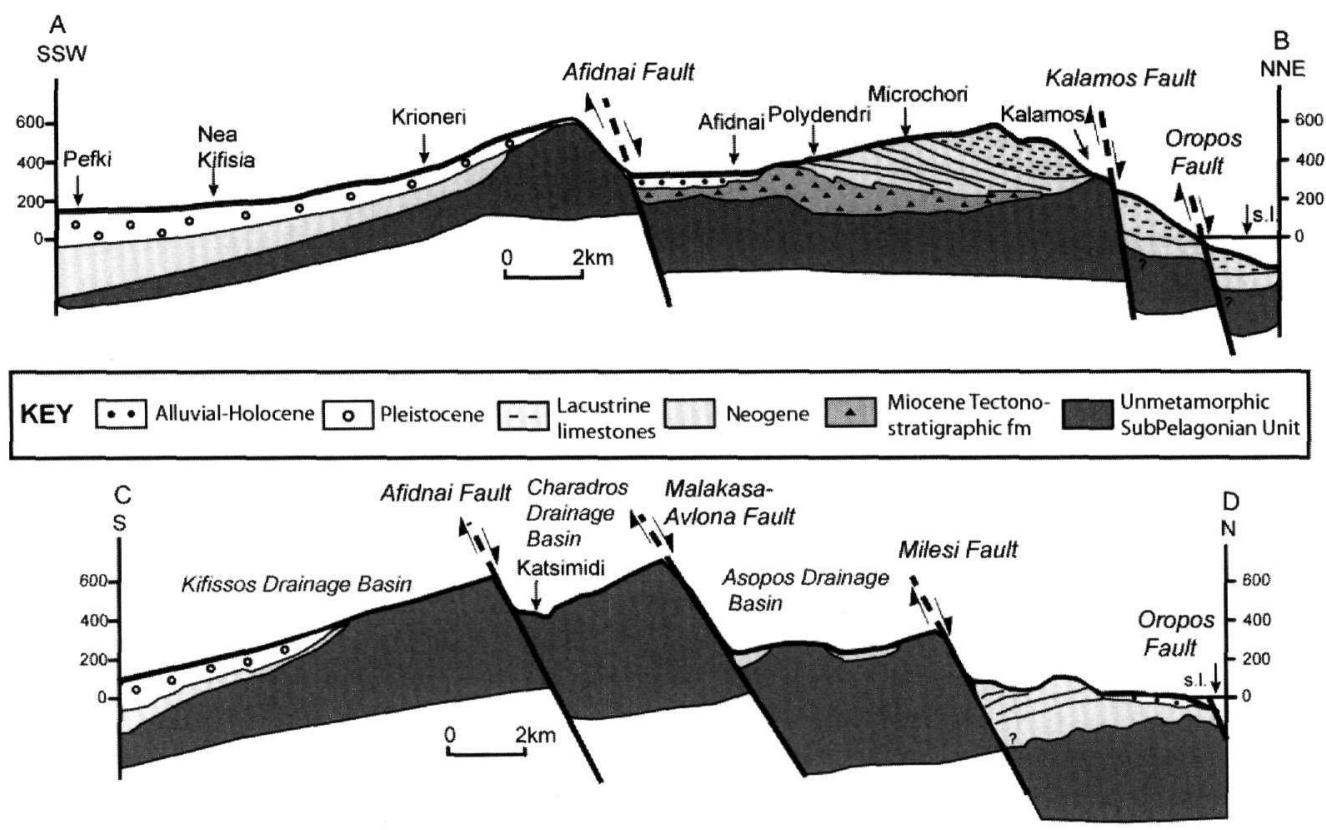

Figure 3 - Cross-sections A-B and C-D (see Fig. 1) 

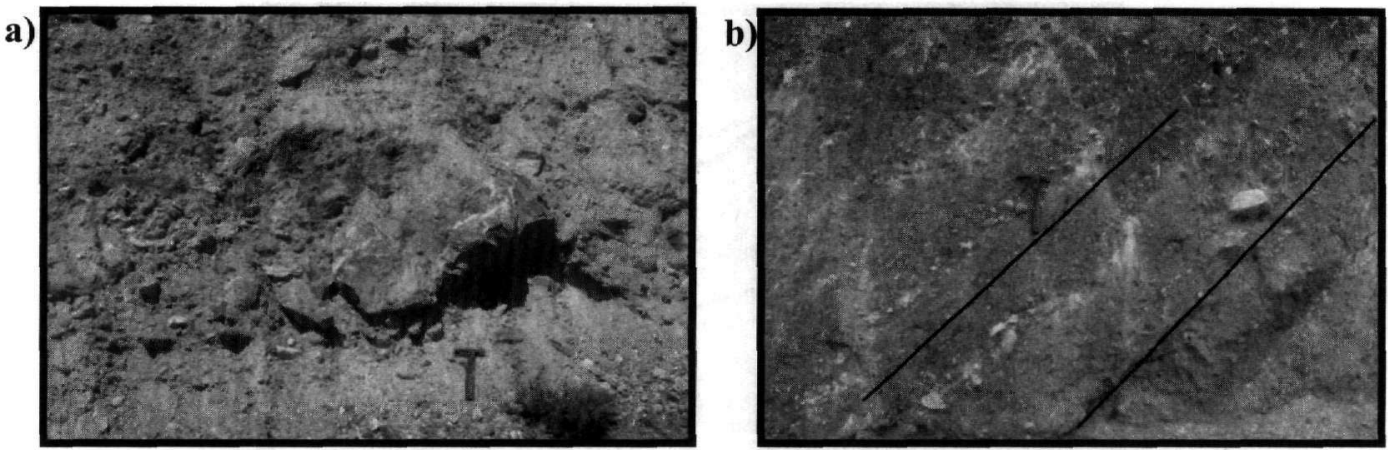

Figure 4 - a) View of the Miocene tectonosedimentary formation of debris-flow deposits in the area of Kapandriti (for location see Fig. 2). Clasts are large (up to a diameter of $2 \mathbf{~ m}$ ), implying that this locality was very close to the detachment trace. b) View of the same formation in the area between Aghios Stefanos and Afidnai in the immediate footwall of the Afindai fault. The bedding plane is nicely revealed, dipping $30^{\circ}-4^{\circ}$ towards NNE. Clasts are relatively small in size rarely exceeding $30-40 \mathrm{~cm}$ in diameter, indicating that this locality was less proximal to the detachment

\section{Geomorphological and neotectonic structure}

The geomorphology of the area is dominated by the Penteli and Parnitha mountains, which border the Athens Plain from the north and the east, respectively. Further north from the southern Evoikos gulf and the coastal zone of Oropos-Kalamos up to the Athens Plain, three major drainage basins are observed: 1) The Kifissos basin in the south with a NNE-SSW flow direction, draining the Athens plain from the southern slopes of Parnitha and the southwestern slopes of Penteli to the Saronic gulf in the southwest. This flow direction is parallel to and near the detachment trace; 2) The Charadros basin with a major W-E flow direction, sourced from the eastern Parnitha highs of about $1200 \mathrm{~m}$ up to the lows of the Afidnai plain and the Marathon lake at about $350 \mathrm{~m}$; 3) The Asopos basin towards the northwest which flows northwards, but has a more complex structure due to the existence of the Avlona-Malakasa and the Milesi faults. Finally, some small approximately N-S trending catchments are observed in the area of Kalamos and the Microchori plateau from $500 \mathrm{~m}$ elevation up to the coast of southern Evoikos.

Drainage basins are highly asymmetric due to the presence of active normal faults. In particular, there is a combination of fault parallel and fault perpendicular flow that is characteristic of active normal faulting settings (Gawthorpe and Hurst 1993, Eliet and Gawthorpe 1995). The tilted footwall results into fault perpendicular flow directions, which drain the footwall away from the hangingwall (e.g. footwall of the Afidnai fault, footwall of the Oropos-Kalamos fault in the area of Kapandriti; see also cross section Fig. 3). On the other hand, headward erosion within the footwall catchments drain across the fault into the hangingwall producing also fault perpendicular flow directions (e.g. Avlona-Malakasa fault, Afidnai fault, Oropos fault). Finally, several catchments are clearly deflected into a fault parallel flow direction due to hangingwall subsidence (e.g. Afidnai fault, Avlona-Malakasa fault, Milesi fault).

The planation surfaces, both erosional and sedimentary, from $50 \mathrm{~m}$ up to $1000 \mathrm{~m}$ in altitude, show an E-W preferred orientation and are usually inclined southwards, indicating a tilt around an E-W axis (Papanikolaou et al. 1988b). This tilt is nicely illustrated in cross-sections (Fig. 3).

Active faults are trending E-W in the northwestern part and NW-SE in the southeastern part; a common tectonic pattern along the Hellenic arc (Mariolakos and Papanikolaou 1981, 1987). The E-W trending faults are large and known to generate medium to large magnitude earthquakes (1938 Oropos $M=6.0,1981$ Alkyonides earthquake sequence $M=6.7, M=6.4, M=6.3,1999$ Athens $\mathrm{M}=5.9$ ), whereas the NW-SE faults occurring in the east are shorter, have lower rates and produce 
low to medium magnitude earthquakes (Papanikolaou and Lozios 1990). This neotectonic pattern has been analysed in the northern Attica through morphotectonic observations (Papanikolaou et al. 1988b), as well as offshore studies in the Saronikos and the southern Evoikos gulfs (Papanikolaou et al. 1988a).

This set of E-W trending north dipping active normal faults in NE Attica consists of: 1) the Oropos-Kalamos fault that is parallel to the coast of the southern Evoikos gulf. It is at least $14 \mathrm{~km}$ long and part of it probably ruptured during the $M=6.0$ event in 1938 . The southern Evoikos gulf is a shallow basin less than $250 \mathrm{~m}$ deep and the main fault of the Gulf has a throw of $250 \mathrm{~m}$ (Papanikolaou et al. 1988a), implying that the Oropos-Kalamos zone as a whole is a relatively small structure and of similar importance as the other across strike faults; 2) the $\sim 10 \mathrm{~km}$ long Milesi fault, which produces a characteristic bedrock scarp on the Mesozoic limestones that form the footwall and the continental Neogene sediments resting on the hangingwall; 3) the $\sim 18 \mathrm{~km}$ long Avlona-Malakasa fault that borders the northern slopes of Parnitha Mt. (Papanikolaou et al. 1988b, Ganas et al. 2004); 4) the $14 \mathrm{~km}$ long Afidnai fault, which bounds the Afidnai plain to the south and the Athens Plain to the north (see also Ganas et al. 2005).

All these faults have produced a cumulative vertical throw of about $2 \mathrm{~km}$ (Fig. 3). The Alpine formations at the top of the Parnitha $\mathrm{Mt}$ at about $1400 \mathrm{~m}$ are buried several hundred meters beneath the present-day sea level and below the Quaternary and the Neogene sediments near the coast of Oropos. The footwall of the Milesi fault is the northernmost Alpine outcrop observed (Figs 1,3 ). These active faults are widely distributed and sharing the strain so that they all exhibit relatively low slip-rates $(<0.5 \mathrm{~mm} / \mathrm{yr})$. However, they are competitive structures distributed across strike lying on each other's stress shadows (Cowie 1998), implying that in the future one of them will prevail.

It is important that the above set of E-W trending active normal faults in northern Attica is constrained exclusively within the non-metamorphic Alpine units. It is also interesting that these faults taper out to the east as approaching the NNE-SSW trending tectonic contact that separates them from the metamorphic units. These observations are in agreement with the disruption model of the Hellenic arc (see Papanikolaou and Royden 2007) which considers: i) the southern Evia / Northern Attica detachment as the southern boundary of the Central Hellenic Shear Zone activated during Miocene to Early Pliocene and ii) the E-W faults developed to the northwest of the detachment, activated since Late Pliocene. Therefore, this detachment indirectly seems to have a significant effect on the neotectonic structure, influencing the geometry, style and intensity of deformation.

\section{The Afidnai fault and the Northern edge of the Athens Plain}

\subsection{The Athens Plain}

In the Late Miocene an E-W trending fault from Attiko Alsos to Kamatero divided the Athens Plain in two sub-basins. The northern part subsided forming a series of lakes throughout Late Miocene-Pliocene, whereas the southern part was tilted to the south with Alpine formations at the northern footwall zone (Attiko Alsos or Tourkovounia) mostly covered by shallow marine sediments in the southern coastal zone of Pireas-Trachones (Papanikolaou et al. 2004b). In Early? -Middle Pleistocene the Kifissos river was formed, cutting through the now inactive E-W fault which previously acted as a barrier. As a result, both subbasins were merged into one, producing what is today known as the Athens Plain (Papanikolaou et al. 2004b). Overall, since Middle Pleistocene the Athens Plain is very similar to the present-day feature. However, one important modification that occurred since Middle Pleistocene concerns the initiation of activity and/or the speeding up of the Afidnai fault. This fault constrained the northern edge of the Athens plain as well as its drainage basin. Due to the backtilting, most of the footwall area is drained by an extensive channel network that flows southwards down the dip footwall slope, forming the upper part of the Kifissos network. The asymmetry of Kifissos drainage basin, where most channels flow 
from Partnitha Mt to the southeast (Fig. 2), illustrates nicely this recent tilt. Also in Middle Pleistocene thick fans and terraces were formed. These planation surfaces observed up to the area south of Krioneri are offset by the Afidnai fault (Fig. 5). As soon as the E-W Kamatero fault became inactive in Middle Pleistocene, the Afidnai fault initiated or took over the extra strain increasing its rate of slip.
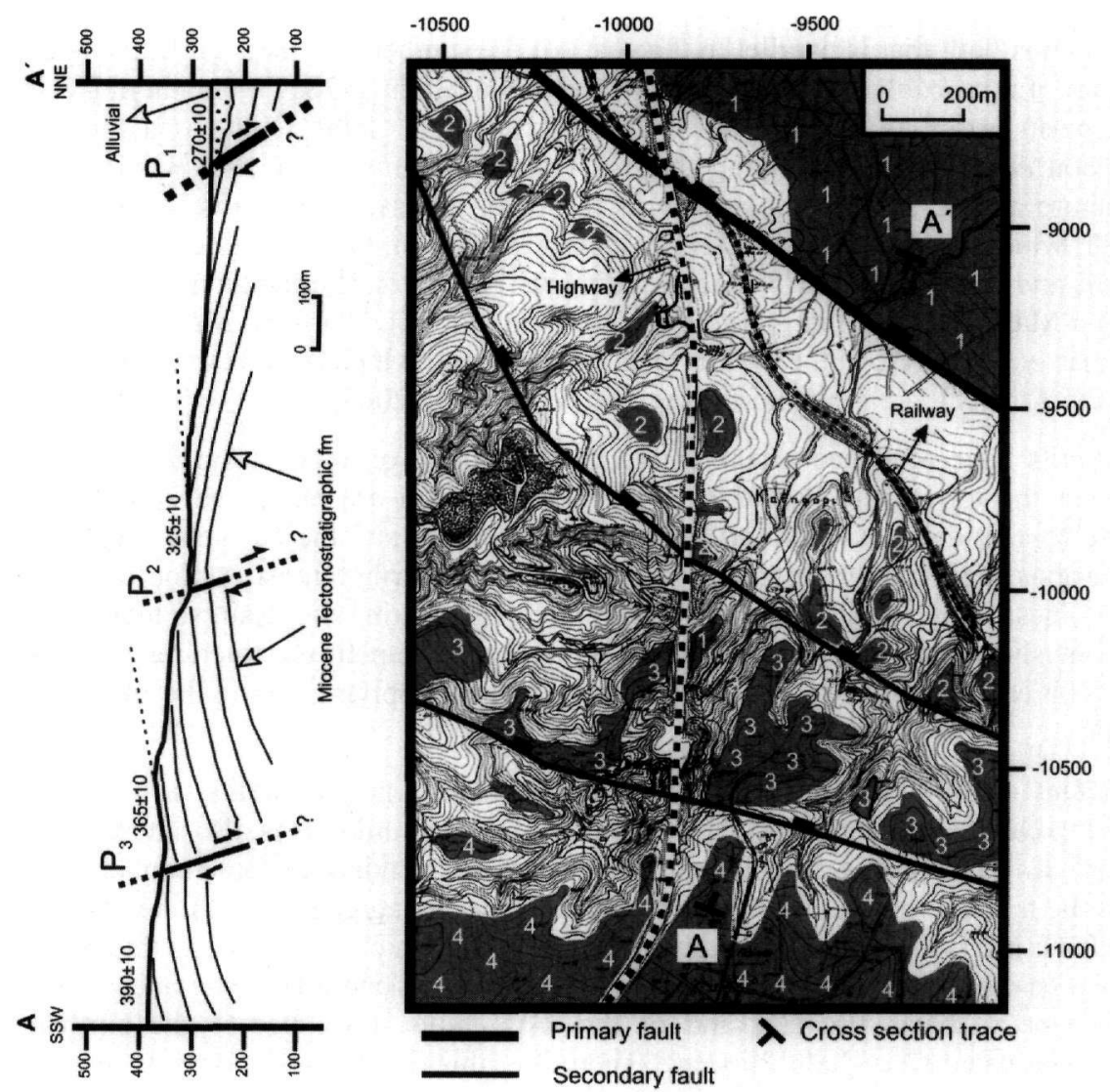

Figure 5 - 1:5000 topographic map (6436/3) and cross-section (A-A') towards the eastern part of the Afidnai fault, showing the traces of the major and the secondary faults and the offset planation surface (for location see Fig. 2)

\subsection{The Afidnai fault}

The Afidnai fault is a E-W trending normal fault, which downthrows to the north and exhibits all the characteristics of an active structure. This fault does generate an impressive morphological footprint, is oriented perpendicular to the present regional extension direction and bounds the Afidnai Quaternary basin. Even though no post-glacial scarps have been identified, there are signs in the geomorphology and drainage, attesting to its recent activity. In particular, the Charadros river is clearly deflected into a fault parallel flow direction due to the subsidence within the Afidnai hangingwall (Fig. 2). Moreover, the Charadros drainage divide is located only several hundred meters southwards from the Afidnai fault in its footwall, but several kilometers northwards from the fault trace in its hangingwall (Fig. 2). The proximity of the footwall watershed to the fault trace, is due to the tilted footwall that produced southward flow directions, which drain the footwall away from the hangingwall. In conclusion, it is suggested that the fault is active for several reasons such as: i) its geometry ( $\sim \mathrm{E}-\mathrm{W}$ trending fault parallel to all other major regional active faults, see Mariolakos and Papanikolaou 1981, 1987 and compatible with the 
regional N-S stress field, Ambraseys and Jackson 1990, Roberts and Ganas 2000, Ganas et al. 2004), ii) its morphological expression (Fig. 6), iii) the fact that it bounds Quaternary sediments, and iv) its drainage pattern.

The Afidnai plain is a local base level. The short distance of the drainage divide on the footwall of the Afidnai fault from the fault trace shows that the dominant route for sediments to enter the adjacent basin in the hangingwall is via short, steep footwall catchments. Therefore, the volume of sediment supply into the Afidnai basin is restricted, resulting into a basin of limited extent and thickness. On the other hand, the limited thickness and spatial distribution of the Quaternary sediments also imply that this base level is recently established. The latter indicates that this fault is relatively young (Early? -Middle Pleistocene fault) that is also in agreement with the paleogeography of the Athens Plain.

The rate at which a fault slips fundamentally determines the seismic hazard because average recurrence intervals tend to decrease as slip-rates increase (e.g. Cowie and Roberts 2001). Unfortunately, the lack of characteristic stratigraphic horizons and postglacial scarps limits our ability to calculate accurately the finite throw or the throw-rate. However, the study of geomorphic features, such as terraces/planation surfaces, can provide us with a first order pattern of displacement. The dense vegetation cover of the Parnitha national park and the highly disturbed topography, due to the existing old clay quarries west of the Athens-Thessaloniki highway, severely limit our observation points. Therefore, we focused our terrace mapping mostly east of the highway, where geomorphology is still relatively undisturbed, even though we are aware that we are closer to the eastern tip of the fault, rather than to the center of it. Detailed 1:5000 mapping of the planation surfaces on the northern edge of the Athens Plain revealed the presence of the main fault at the base of the hillside and two secondary faults on the footwall of the main fault. It is unclear whether the secondary faults are still active or that activity may have shifted to the lower major fault following a progressive hangingwall directed migration within the fault zone (Stewart and Hancock 1994). The Afidnai fault separates the major Athens plain from the minor AfidnaiLake-Marathon Plain. The present day Afidnai basin on the immediate hangingwall of the Afidnai fault lies at $270 \pm 10 \mathrm{~m}$, whereas the northern edge of the Athens basin is at $390 \pm 10 \mathrm{~m}$, implying a minimum finite throw of $120 \mathrm{~m}$. Half of this throw is accommodated by the main fault at the base and the other half from the two secondary faults towards the footwall, which are probably linked at depth with the main fault. Considering an Early Pleistocene age (between 1.0 to $1.5 \mathrm{Ma}$ ) of the planation surface (see also 4.1), we calculate a long-term throw-rate of $0.08-0.12 \mathrm{~mm} / \mathrm{yr}$. However, this rate is extracted from a locality, which is closer to the eastern tip of the fault, rather than to the center of it (Fig. 6). The latter suggests that we may underestimate the rate towards the center of the fault (Papanikolaou and Roberts 2006), because fault slip and slip-rates vary along strike the fault and increase systematically along strike from zero at the fault tips, to maxima towards its center (e.g. Cowie and Scholz 1992). The latter can be nicely observed on the panoramic view of the fault taken from the area of Kapandriti, showing how displacement progressively decreases to minima as approaching the eastern tip of the fault (Fig. 6). Considering that the finite throw towards the center of the fault is about 3 times higher $(\sim 360 \mathrm{~m}$, see also Ganas et al. 2005 who calculate a $350 \mathrm{~m}$ relief based on DEM analysis), the maximum rate is about $0.30 \mathrm{~mm} / \mathrm{yr}$. Following the above discussion, we estimate a mean rate of $0.15-0.20 \mathrm{~mm} / \mathrm{yr}$ for this fault. This value is similar to the value extracted from Ganas et al. (2005). They based on DEM morphometry and made an empirical suggestion that slope angle is a function of the long-term fault slip-rate, which varies between $0.13-0.30 \mathrm{~mm} / \mathrm{yr}$. For the Afidnai fault they calculated a $0.15-0.19 \mathrm{~mm} / \mathrm{yr}$, but using a conservative (4-5 Ma) age constrain. In such a low throw-rate, no postglacial fault scarps or well-shaped bedrock scarps with a free face can be revealed. This occurs because erosion and sedimentation rates are higher and outpace the fault throw-rate.

Even though this fault offsets the Miocene tectonostratigraphic formation, it seems that its eastern tip is located close to the detachment trace, showing once again that the detachment plays a fundamental role in the region (Fig. 1). Further to the east and north from the Dionysos fault, two 
NW-SE trending possibly active faults may take over the strain from the Afidnai fault, but no straightforward link to the Afidnai fault can be supported. They leave a rather subtle trace in the morphology and no significant throws can be calculated.

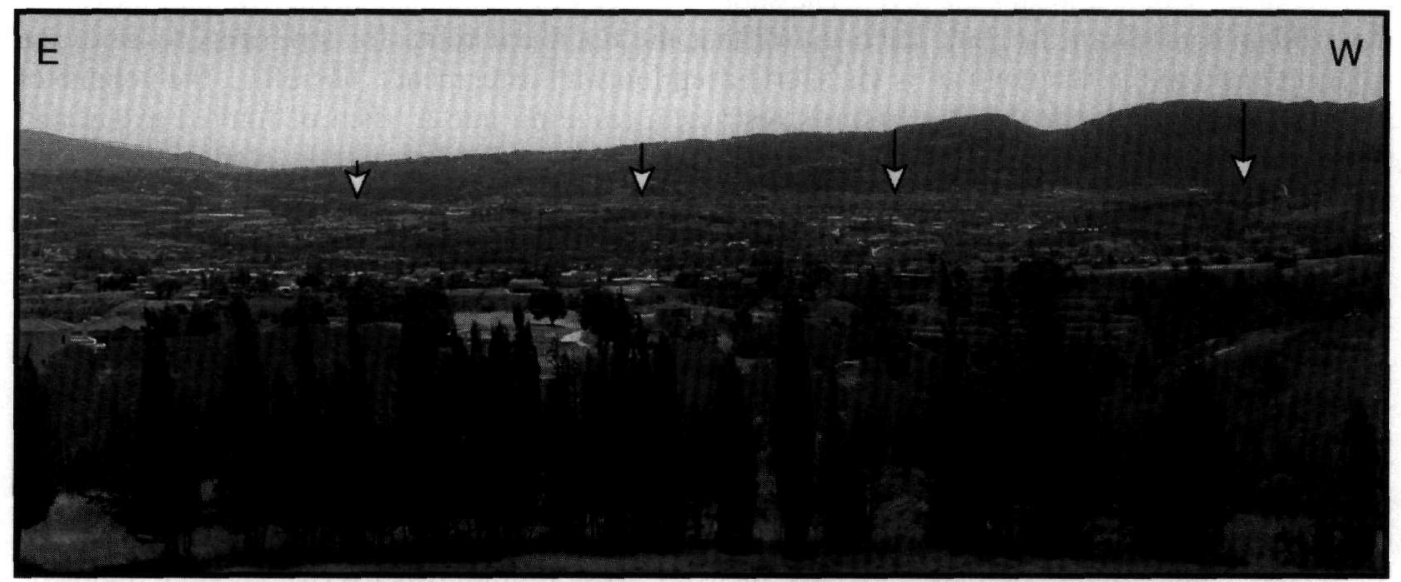

Figure 6 - Panoramic view of the Afidnai fault geometry (photo taken from Kapandriti).

Footwall elevation tends to decrease away from the fault centre. Therefore, displacement decreases to minima as approaching the eastern tip of the fault

\subsection{Seismic hazard assessment}

Following the historical catalogue, no large events $(\mathrm{M}>6.5)$ or severe damages have been recorded in NE Attica (Galanopoulos 1955, Papazachos and Papazachou 1997). Only two events have been recorded, the Oropos event in 1938 and another earthquake in 1705. The 1938 Oropos event $(\mathrm{Ms}=6.0)$ probably ruptured part of the Oropos offshore fault or the shorter Milesi fault (Fig. 1), generating macroseismic intensity VIII and 18 fatalities (Papazachos and Papazachou 1997). No primary surface ruptures have been observed or documented, but several landslides occurred particularly in the area of Malakasa. As far as the 1705 event (Ambraseys and Jackson 1997) is concerned, there is uncertainty concerning both the magnitude (M 6.4 according to Papazachos and Papazachou 1997) and predominantly the epicentral area. Minor damages were inflicted both to the towns of Athens and Chalkida, so that researchers place the epicenter towards the NE flanks of the Parntitha mountain. It is possible that the Afidnai fault could have ruptured during the 1705 event, however the limited data extracted from the historical record cannot confirm or deny such an interpretation (e.g. it could be also the Malakasa-Avlona fault). The historical record is considered complete for shallow events $(h<60 \mathrm{~km})$ for $M>6.5$ since 1845 and for $M>7.3$ since 1500 (Papazachos et al. 2000). Therefore, it is also possible that an earthquake of $\mathrm{M}=6.0$ to 6.4 could have occurred before the year 1845 and for several reasons has not been recorded.

The worse case scenario implies the rupture of the entire $14 \mathrm{~km}$ long Afidnai fault. Based on the equation between Magnitude (M) and surface rupture length (SRL) of the worldwide dataset of Wells and Coppersmith (1994), this fault can generate a $M=6.4$ event. A similar magnitude $(\mathrm{Ms}=6.5)$ is also calculated based on Pavlides and Caputo (2004) empirical relationships from normal faulting events of the Aegean, which may be more representative of the local geotectonic conditions. Ganas et al. (2005) estimated the fault as $11 \mathrm{~km}$ and calculated a similar Magnitude $(\mathrm{Ms}=6.4)$. Considering a mean slip-rate in the order of $0.15-0.20 \mathrm{~mm} / \mathrm{yr}$ and that all slip is released in earthquakes of the maximum magnitude $(\mathrm{M}=6.4)$, therefore assuming a worst-case scenario, we calculate a recurrence interval of about 2000 years.

Taking into account that the completeness of the historical record for such magnitude events covers time periods of a few hundreds years and probably shorter than 500 years (e.g. Papazachos et al. 2000), it is evident that the recurrence interval is only a fraction of the completeness period. 
Therefore, either this fault has not been activated in historical times or it was activated, but for whatever reason such an event was not recorded in the historical catalogues. Finally, if this fault indeed ruptured in 1705 , then the probability for a future event in the near future generated by this source is rather negligible.

\section{Discussion-Conclusions}

Relief in NE Attica is mainly influenced by fault geometry and fault spacing. Drainage basins are highly asymmetric, producing a combination of fault parallel (E-W) and fault perpendicular (N-S) flow directions. The closely spaced faults produce secondary narrow highs and lows due to the interference between displacement fields, influencing also the drainage divide. The Afidnai fault bounds the northern edge of the Athens Plain and separates it from the secondary Afidnai Plain. It is active, but exhibits a low slip-rate. We have used offset Pleistocene terraces to calculate a longterm throw-rate of 0.1 to $0.3 \mathrm{~mm} / \mathrm{yr}$ for the Afidnai fault, depending on the actual terrace Pleistocene age estimates and our location along strike the fault. This fault is probably active since Early? -Middle Pleistocene and based on a worst-case scenario, it can generate events of the maximum magnitude $(M=6.4)$, about every 2000 years. Therefore, the completeness of the historical record is much shorter than the mean earthquake recurrence interval of the Afidnai fault.

The NE Attica is also divided by a major NNE-SSW detachment fault that separates the metamorphic units to the east from the unmetamorphic units to the west. This detachment also separates the E-W trending faults towards the western part from the NW-SE trending less active faults towards the eastern part. It was active in Late Miocene-Early Pliocene and produced several hundred meters of debris-flow deposits. It is important that the set of E-W trending active normal faults in northern Attica is constrained exclusively within the non-metamorphic Alpine units and that these faults taper out to the east as approaching the detachment zone. Therefore, this detachment indirectly seems to have a significant effect on the neotectonic structure, influencing the geometry, style and intensity of deformation.

Finally, it is interesting to note that this NNE-SSW trending detachment influences also the seismicity pattern. More precisely, it coincides with the line separating zone I (lowest category of seismic risk) from zone II (intermediate zone) of the national seismic building code (EAK-2003), which have been compiled based on the seismicity level (E.P.P.O.-A.C.E.G., 2001). This is also in agreement with the damage pattern of the 1999 Athens Earthquake, where this detachment further to the south (e.g. inside the Athens Plain) played an important role to the intensity distribution (Papanikolaou et al. 1999, Marinos et al. 1999), forming a boundary between higher and lower intensities. More precisely, significantly higher damages were produced to sites located both along strike its trace and west from it, within the non-metamorphic units, compared to the sites situated east of the detachment. Therefore, this detachment even though it is inactive, still exerts a significant influence on the present day geological, geomorphological, neotectonic and seismicity pattern, showing how old and new structures interrelate and interact.

\section{Acknowledgments}

We thank S. Papaspyrou and A. Dovas for their collaboration within the Technopolis-Acropolis Project that gave us the opportunity to study the northern edge of the Athens Plain. Reviews from R. Caputo and E. Vittori improved the manuscript.

\section{References}

Ambraseys, N.N., and Jackson, J.A., 1990. Seismicity and associated strain of central Greece between 1890-1988, Geoph. J. Int, 101, 663-708.

Ambraseys, N.N., and Jackson, J.A., 1997. Seismicity and strain in the Gulf of Corinth (Greece) since 1694, J. Earth. Eng., 1, 663-708. 
Cowie, P. A., 1998. A healing-reloading feedback control on the growth rate of seismogenic faults, J. Struct. Geol., 20, 1075-1087.

Cowie, P. A., and Roberts, G. P., 2001. Constraining slip rates and spacings for active normal faults, J. Struct. Geol., 23, 1901-1915.

Cowie, P. A., and Scholz, C. H., 1992. Physical explanation for displacement-length relationship for faults using a post-yield fracture mechanics model, J. Struct. Geol., 14, 1133-1148.

Dubois, R., and Bignot, G., 1979. Presence d' un "hard-ground" nummulitique au sommet de la serie cretace d' Almyropotamos (Eubee meridionale, Grece). Consequences, C.R. Acad. Sci. Paris, 289, 993-995.

Eliet, P.P., and Gawthorpe, R.L., 1995. Drainage development and sediment supply within rifts, examples from Sperchios basin mainland Greece, J. Geol. Soc. Lond., 152, 883-893.

E.P.P.O.-A.C.E.G., 2001. Greek Seismic Design Code 2000. Earthquake Planning and Protection organization, Assoc.Civil Engineers, Government Gazette 2184B/20-12-99, Athens, $257 \mathrm{pp}$.

Galanopoulos, A., 1955. Erdbegeographie von Griechenland, Ann. Geol. Pays Hellen., 6, 83-122. (in Greek)

Gawthorpe, R., and Hurst, J., 1993. Transfer zones in extensional basins: their structural style and influence on drainage development and stratigraphy, J. Geol. Soc. Lond, 150, 1137-1152.

Ganas, A., Pavlides, S.B., Sboras, S., Valkaniotis, S., Papaioannou, S., Alexandris, G.A., Plessa, A., and Papadopoulos, G.A., 2004. Active fault geometry and kinematics in Parnitha Mountain, Attica, Greece, J. Struct. Geol., 26, 2103-2118.

Ganas, A., Pavlides, S., and Karastathis, V. 2005. DEM-based morphometry of range front escarpments in Attica, central Greece and its relation to fault slip-rates, Geomorph., 65, 301-319.

Guernet, C., and Sauvage, J., 1970. Obervations nouvelles sur le Néogène de la région de Pikermi et Rafina (Attique Grèce), Bull. Soc. Geol. France, 12, 241-245.

Katsikatsos, G., 1969. Age of the metamorphic system of S. Evia and its stratigraphic structure, Praktika Acad. Athinon, 44, 223-238. (in Greek)

Katsikatsos, G., 1979. La structure tectonique de 1' Attique et de 1' ile d' Eubee, Proc. $6^{\text {th }}$ Coll. Geol. Aegean Region, 1, 211-228.

Lozios, S., 1993. Tectonic analyisis of the metamorphic rocks in NE Attica, Unpublished Ph.D. thesis, Department of Geology, University of Athens, 299pp. (in Greek)

Marinos, P., Boukouvalas, G., Tsiambaos, G., Pronotarios, G., and Sabatakakis, N., 1999. Damage distribution in the western part of Athens after the 7-9-99 earthquake, Newsletter of E.C.P.F.E., Counsil of Europe, Issue No 3, 36-39.

Mariolakos, I., and Papanikolaou, D., 1981. The Neogene basins of the Aegean Arc from the Paleogeographic and the Geodynamic point of view, Proc. Int. Symp. H.E.A.T., 383-399.

Mariolakos, I., and Papanikolaou, D., 1987. Deformation pattern and relation between deformation and seismicity in the Hellenic Arc, Bull. Geol. Soc. Greece, 19, 59-76.

Mettos, A.I., 1992. Geological and paleogeographical study of the continental Neogene and Quaternary deposits of NE Attica and SE Beotia, Unpublished Ph.D. thesis, Department of Geology, University of Athens. (in Greek)

Mitzopoulos, M., 1948. Das Pliozan ron Raphina, Prakt. Akad. Athinon, 23, 295-301. 
Papanikolaou, D., 1986. Geology of Greece (in Greek). Eptalofos Publications, Department of Geology, University of Athens, 240pp.

Papanikolaou, D., Lykoysis, V., Chronis, G., and Pavlakis, 1988a. A comparative study of neotectonic basins across the Hellenic arc: the Messiniakos, Argolikos, Saronikos and Southern Evoikos gulfs, Basin Research, 1, 167-176.

Papanikolaou, D., Mariolakos, I., Lekkas, E. and Lozios, S., 1988b. Morphotectonic observations on the Asopos Basin and the coastal zone of Oropos. Contribution on the neotectonics of Northern Attica, Bull. Geol. Soc. Greece, 20, 252-267

Papanikolaou, D., and Lozios, S., 1990. Comparative neotectonic structure of high (KorinthiaBeotia) and low rate (Attica-Cyclades) activity, Bull. Geol. Soc. Greece, 26, 47-66. (in Greek)

Papanikolaou, D., Lekkas, E., Sideris, C., Fountoulis, I., Danamos, G., Kranis, C., Lozios, S., Antoniou, I.,. Vassilakis, E., Vasilopoulou S., Nomikou, P., Papanikolaou, I., Skourtsos, E., and Soukis, K., 1999. Geology and tectonics of Western Attica in relation to the 7-9-99 earthquake, Newsletter of E.C.P.F.E., Council of Europe, Issue No 3, 30-34.

Papanikolaou, D.I., Lozios, S.G., Soukis, K., and Skourtsos, E., 2004a. The geological structure of the Allochtonous "Athens Schists", Bull. Geol. Soc. Greece, 36, 1550-1559.

Papanikolaou, D., Bassi, E, Kranis, H., and Danamos, G., 2004b. Paleogeographic evolution of the Athens basin from upper Miocene to Present, Bull. Geol. Soc. Greece, 36, 816-825.

Papanikolaou, D., and Royden, L., 2007. Disruption of the Hellenic arc: Late Miocene extensional detachment faults and steep Pliocene-Quaternary normal faults - or - What happened at Corinth? Tectonics, in press.

Papanikolaou, I., and Roberts, G., 2006. Slip-rate variability along strike active faults: Implications for seismic hazard assessment and mapping, Geoph. Res. Abstr. 8, 07078, EGU Vienna.

Papazachos, B.C., and Papazachou, C.B., 1997. The earthquakes of Greece. Ziti editions, Thessaloniki, 304pp.

Papazachos, B.C., Comninakis, P.E., Karakaisis, G.F., Karakostas, B.G., Papaioannou, C.A., Papazachos, C.B., and Scordilis, E.M., 2000. A catalogue of earthquakes in Greece and surrounding area for the period 550BC-1999, Publ. Geoph. Lab.University of Thessaloniki.

Pavlides, S., and Caputo, R., 2004. Magnitude versus faults' surface parameters: quantitative relationships from the Aegean Region, Tectonophysics, 380, 159-188.

Roberts, G. P., and Ganas, A., 2000. Fault-slip directions in central-southern Greece measured from striated and corrugated fault planes: comparison with focal mechanism and geodetic data, J. Geophys. Res., 105, 23,443-23,462.

Roubanis, B.S., 1961. Geological research on the Parnes mountain range, Annales Geologiques des Pays Helleniques, 12, 18-104.

Schliestedt, M., Altherr, R., and Matthews, A., 1987. Evolution of the Cycladic crystalline complex: petrology, isotope geochemistry and geochronology. In R. Helgeson (ed.), Chemical transport in metasomatic processes. NATO Advanced Study Institute Series C, Reidel, Dordrecht, 218, 389-428pp.

Stewart, I.S., and Hancock, P.L., 1994. Neotectonics. In P.L. Hancock (ed.), Continental deformation Pergamon Press, 370-409pp. 
Wells, D.L., and Coppersmith, K. J., 1994. New empirical relationships among magnitude, rupture length, rupture width and surface displacement, Bull. Seism. Soc. America, 84, 974-1002.

Xypolias, P., Kokkalas, S., and Skourlis, K., 2003. Upward extrusion and subsequent transpression as a possible mechanism for the exhumation of HP/LT rocks in Evia island (Aegean Sea, Greece), J. Geodyn., 35, 303-332. 